\title{
MINERALOGICAL AND CHEMICAL VARIATIONS INDUCED BY TROPICAL WEATHERING OF GRANULITIC ROCKS FROM THE BRAZILIAN BASEMENT
}

\author{
G. P. SIGHINOLFI*, L. S. P. de AZEVEDO, P. S. LINHARES** and A. C. MONIZ***
}

ABSTRACT Chemical and mineralogical transformations occurring during tropical weathering of granulitic rocks from the Brazilian basement have been studied. Granulite weathering produces either gibbsitic or kaolinitic soil, as well as kaolinitic-gibbsitic soil. The transition from one type to another is abrupt and occurs in very limited areas. The variation in the chemical composition of host-rocks and/or in the drainage conditions seems to account for the above soils variation.

The residual soil is characterized by the almost total diseappearance of alkali and alkaline earths and by strong enrichment of some hydrolized elements, like $\mathrm{Zr}$, $\mathrm{Ti}$ and $\mathrm{Cr}$. Relationships between ferromagnesian elements and iron both in rocks and in soil have been discussed in detail.

RESUMO Estudaram-se transformações químicas e mineralógicas que ocorrem durante o intemperismo de rochas granulíticas do embasamento brasileiro. $\mathrm{O}$ intenso intemperismo produz solos gibbsíticos, cauliníticos ou caulinítico-gibbsíticos. A transição de um tipo para outro é abrupta e ocorre em pequenas áreas, provavelmente devido às variações na composição química da rocha matriz e/ou das condições de drenagem.

O solo residual é caracterizado pelo desaparecimento quase que total dos elementos alcalinos e alcalino-terrosos e pelo forte enriquecimento de alguns elementos hidrolizados, como o Zr, Ti e Cr. Discutiram-se pormenorizadamente relações entre elementos ferromagnesianos e o ferro, em rochas inalteradas e em solos residuais.

INTRODUCTION Chemical and mineralogical transformations occurring in soil formation under tropical weathering conditions from various types of rock have been widely studied by numerous authors (McLaughlin, 1955; Bonifas, 1959; Delvigne, 1965 and 1967; Fairbairn and Robertson, 1966; Tardy, 1969; Sieffermann, 1969; Haantjens and Bleeker, 1970). Weathering of high-grade metamorphic rocks, granulites in particular, has not been studied specifically, although most work deals at least partially with weathering of metamorphic rocks such as gneisses and migmatites (Grant, 1964; Kabata-Pendias and Ryka, 1968; Melfi and Levi, 1971; Levi and Melfi, 1972).

The interesting aspects found when studying granulite weathering are their peculiar structures, the fact that their mineralogical and chemical features may at least áffect the type of soil produced, and that large areas of the African and Brazilian shields present granulites as principal country rocks. In addition, it would be interesting to analyze the geochemical behaviour of some elements in the residual soils, taking as the starting point geochemical trends given in recent work (Sighinolfi, 1970 and 1971) on granulites. Thus the aim of this paper is to obtain new mineralogical and chemical data on the tropical weathering of granulites and to investigate the detailed behaviour of elements during the formation of residual soils.

*Instituto di Mineralogia e Petrologia, Universitá di Modena, Modena, Italy

**Instituto de Geociências, Universidade Federal da Bahia. Salvador, Brazıl

***Instituto Agronômico do Estado de São Paulo, Campinas, SP, and Conselho Nacional de Pesquisas 
Parent material and general features of the profile considered Material from a very limited area situated $12 \mathrm{~km}$ near Salvador (Bahia, Brazil) was selected for study. This area is situated within the Pedreira Valeria district. Here, the host-rocks belong to the undifferentiated precambrian basement.

PETROLOGY The petrology of this area and the surrounding regions was described by Oliveira (1970) and by Fujimori (1968). According to Oliveira (1970) several types of granulitic rocks occur in which banded "basic" granulites predominate and which show various mineralogical parageneses. The most common granulite consists of the assemblages: quartz-andesite-hornblende-biotite; andesine-hornblende-biotite-hyperstene-diopside and andesite-hyperstene-biotite-magnetite. The diffuse blackening over all the rock types produces a false homogeneity and prevents the rapid field identification of banding in granulites. Three soil profiles developed by weathering of granulites were selected on an elliptic front of approximatively $300 \mathrm{~m}$ length. Over all the area the zone of weathering extends variably to a maximum depth of $50 \mathrm{~m}$, and most of the soils are composed of coherent, easy to identify, altered rocks. Above this a layer of light-yellow material of variable thickness is found, and is in turn overlain by a more dark horizon which grades into a black organic-rich zone which continues to the surface. The $\mathrm{pH}$ measured at different soil levels varies between 4.0 and 6.0. In profiles A and B (Table I) most of the values fall in the range 4.0-5.0, and in that of $\mathrm{C}$ between 4.8 and 5.3. Table I reports for each profile the depth at which the samples were collected with the vertical distance given with respect to the contact of the fresh rock with the altered material taken as zero. Sample B10 is an unaltered inclusion above the line of rock weathering.

Table I - Sample position in relation to the contact between fresh granulite and overlaying residual soil

\begin{tabular}{|c|c|c|c|c|c|c|}
\hline & \multicolumn{2}{|c|}{ Profile A } & \multicolumn{2}{|c|}{ Profile B } & \multicolumn{2}{|c|}{ Profile C } \\
\hline & $\begin{array}{l}\text { Sample } \\
\text { number }\end{array}$ & $\begin{array}{l}\text { Distance from } \\
\text { the contact, } \mathrm{m}\end{array}$ & $\begin{array}{l}\text { Sample } \\
\text { number }\end{array}$ & $\begin{array}{l}\text { Distance from } \\
\text { the contact, } \mathrm{m}\end{array}$ & $\begin{array}{l}\text { Sample } \\
\text { number }\end{array}$ & $\begin{array}{l}\text { Distance from } \\
\text { the contact, } m\end{array}$ \\
\hline \multirow{6}{*}{$\begin{array}{l}\text { Fresh } \\
\text { granulite }\end{array}$} & A1 & 25 & B1 & 20 & $\mathrm{C} 5$ & 30 \\
\hline & A2 & 20 & B2 & 10 & $\mathrm{C} 7$ & 20 \\
\hline & A3 & 10 & B5 & 1 & C6 & 15 \\
\hline & A4 & 1 & B3 & 0.2 & $\mathrm{C} 10$ & 2.5 \\
\hline & A5 & 0.03 & B10 & $*$ & C1 & 1 \\
\hline & & & & & $\mathrm{C} 11$ & 0.1 \\
\hline \multirow{7}{*}{$\begin{array}{l}\text { Residual } \\
\text { soil }\end{array}$} & A9 & 0.1 & B6 & 0.8 & $\mathrm{C} 2$ & 0.5 \\
\hline & A5 & 1 & B4 & 1.2 & $\mathrm{C} 8$ & . 1 \\
\hline & A 10 & 1.5 & B9 & 3 & C3 & 3 \\
\hline & A6 & 2.5 & B7 & 4 & $\mathrm{C} 4$ & 4 \\
\hline & A11 & 3.5 & B8 & 4.5 & $\mathrm{C} 12$ & 6 \\
\hline & A7 & 5 & B10 & 5 & C13 & 12 \\
\hline & & & & & C14 & 15 \\
\hline
\end{tabular}

*Boulder of fresh rock found in the residual soil at 3 meters above the contact

GLIMATIC CONDITIONS Glimatic conditions are very steady and are characterized by very high rainfall (up to $1,800 \mathrm{~mm}$ ) an by an average temperature of $25^{\circ} \mathrm{C}$.

DRAINAGE Field observations supported by the mineralogical and chemical data of this work suggest that alteration has occurred under conditions of very strong drainage. 
ANALYTICAL METHODS Major elements were determined by AA spectroscopy using the decomposition procedure described by Bernas (1968) and modified by the authors in some details. Each sample was analyzed in duplicate. The analytical error for major elements can be evaluated as in Bernas (1968). V, Cu, Zr, Ni and Co were determined by optical spectrography by methods described by Sighinolfi (1966 and 1968). Cr and Zn were determined by AA spectroscopy following Belt (1964). The analytical error for most of the trace elements is estimated to be $10 \%$. Standardization for all the elements was made using the USGS rock standards to obtain calibration curves.

ANALYTICAL RESULTS AND DISCUSSION MINERALOGY OF RESIDUAL SOIL According to the X-ray analysis the residual soil has as main secondary minerals either gibbsite or kaolinite, as well as a mixture of both minerals (Fig. 1). Goethite and a

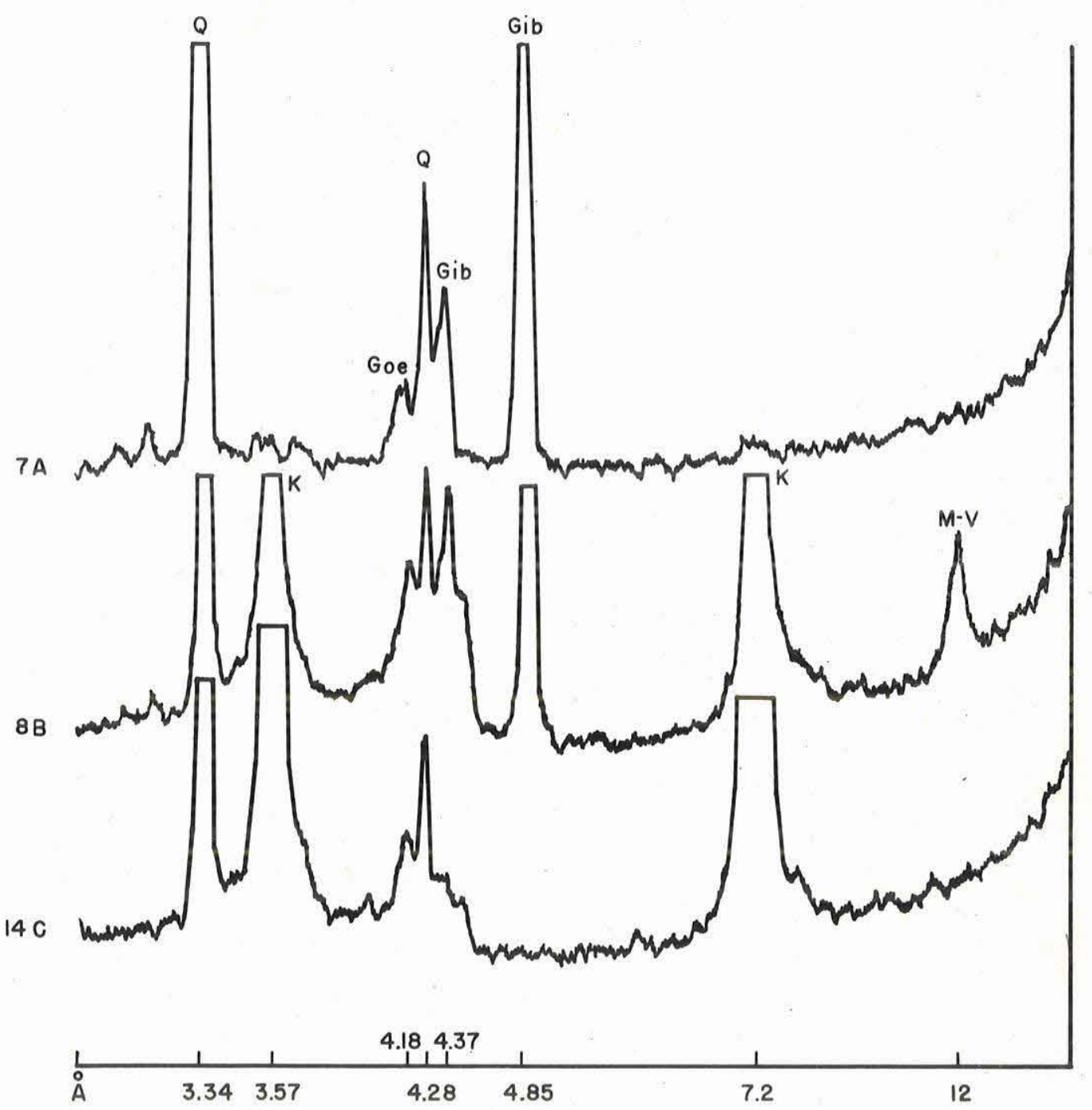

Figure 1 - Diffractograms of orientated clay layers of Samples A7, B8 and 14C. Gib: gibbsite; $Q$ : quartz; Goe: goethite; $M-V$ : mixed-layered mica-vermiculite and $K$ : kaolin 


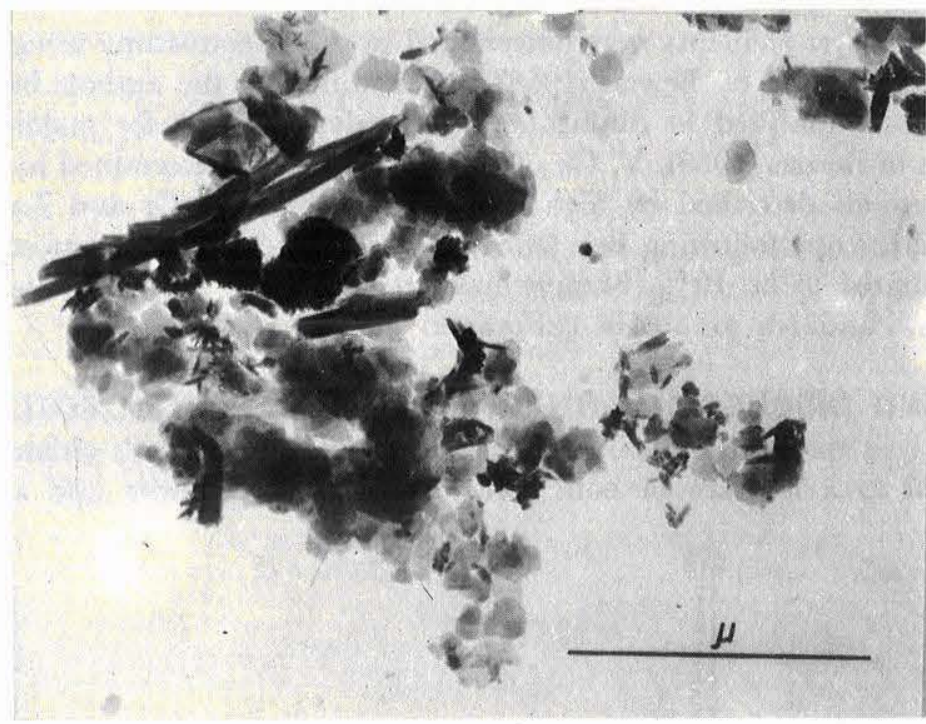

Figure 2 - Electron micrography of a kaolinitic material from profile $\mathrm{C}$ showing tubes of halloysite associated with plates of kaolinite

mixed-layer mica-vermiculite were found frequently. The latter is derived probably from the biotite. Halloysite was identified with electron microscope analysis and seems to be also one of the main components of the residual soil (Fig. 2). Quartz was identified in all samples. According to the Fig. 1 the mineralogical composition of the residual soil varies abruptly over very limited areas. Thus the gibbsite content, which can be used as weathering index (Moniz and Jackson, 1967) presented a wide variation, from zero to $52 \%$ (Table II). The variation in the chemical composition of the host-rocks and/or in the drainage conditions seems to account for the above mineralogical variation.

Table II - Gibbsite content of some residual soils determined by DTA method

\begin{tabular}{cccccc}
\hline Sample & Gibbsite, $\%$ & Sample & Gibbsite, $\%$ & Sample & Gibbsite, $\%$ \\
\hline \hline A10 & 17 & B6 & 24 & C8 & 9 \\
A6 & 44 & B4 & 31 & C4 & 33 \\
A11 & 43 & B7 & 52 & C12 & 0 \\
A7 & 34 & B8 & 21 & C14 & 0 \\
\hline
\end{tabular}

CHEMICAL DATA 16 samples of fresh rock and 19 samples of altered material were analyzed for major and trace elements, and the results are reported in Table III and IV. Averages and dispersion data for all the elements in rocks and soil are also reported. The values of the coefficient of variation ( $C$ per cent) demonstrate that chemical heterogeneity characterizes the granulitic parent material. Furthermore, a still stronger dispersion of main and trace elements in the residual soil is demonstrated.

Estimates of gain and loss for main elements in the weathering within the three profiles, calculated as suggested by Krauskopf (1967, p. 103), are reported in Table V. These calculations were made on the assumption commonly retained (see for example Craig and Loughnan, 1964) that alumina does not change appreciably under normal weathering conditions. Nevertheless, a partial loss of alumina under conditions of very strong drainage and appropriate $\mathrm{pH}$ must be considered (see for example Delvigne, 1965; Hendricks and Whitting, 1968). 
Table III - Chemical composition of fresh granulite

\begin{tabular}{|c|c|c|c|c|c|c|c|c|c|}
\hline & A1 & A2 & A 3 & A4 & A 8 & B1 & B2 & B3 & B5 \\
\hline $\mathrm{SiO}_{2}$ & 55.36 & 55.92 & 55.99 & 53.38 & 60.06 & 53.51 & 51.81 & 53.96 & 55.25 \\
\hline $\mathrm{TiO}_{2}$ & 1.91 & 1.83 & 1.32 & 2.24 & 0.50 & 0.77 & 0.86 & 0.71 & 0.73 \\
\hline $\mathrm{Al}_{2} \mathrm{O}_{3}$ & 14.37 & 15.91 & 15.44 & 15.91 & 18.05 & 17.60 & 16.85 & 17.27 & 15.73 \\
\hline $\mathrm{Fe}_{2} \mathrm{O}_{3}$ & 0.09 & 0.71 & 1.17 & 0.38 & 1.47 & 1.99 & 2.51 & 1.59 & 1.84 \\
\hline $\mathrm{FeO}$ & 10.81 & 10.48 & 9.48 & 11.25 & 6.27 & 8.99 & 8.98 & 7.86 & 8.71 \\
\hline $\mathrm{MnO}$ & 0.082 & 0.086 & 0.108 & 0.132 & 0.061 & 0.116 & 0.142 & 0.126 & 0.140 \\
\hline $\mathrm{MgO}$ & 3.18 & 2.18 & 2.63 & 3.75 & 1.58 & 5.11 & 4.18 & 4.32 & 4.25 \\
\hline $\mathrm{CaO}$ & 5.75 & 4.78 & 4.83 & 6.75 & 4.82 & 9.21 & 9.02 & 8.30 & 6.95 \\
\hline $\mathrm{Na}_{2} \mathrm{O}$ & 3.17 & 3.22 & 3.72 & 2.83 & 4.07 & 0.75 & 3.20 & 3.30 & 3.04 \\
\hline $\mathrm{K}_{2} \mathrm{O}$ & 3.72 & 3.75 & 3.74 & 2.45 & 2.53 & 0.81 & 1.25 & 1.24 & 2.03 \\
\hline $\mathrm{H}_{2} \mathrm{O}^{+}$ & 0.00 & 0.00 & 0.10 & 0.00 & 1.03 & 0.00 & 0.13 & 0.23 & 0.12 \\
\hline Total & 98.44 & 98.86 & 98.45 & 99.07 & 100.44 & 98.86 & 98.93 & 98.91 & 98.79 \\
\hline Total Fe* & 12.09 & 12.34 & 11.69 & 12.87 & 8.43 & 11.97 & 12.48 & 10.31 & 11.51 \\
\hline \multicolumn{10}{|c|}{ Trace elements (ppm) } \\
\hline V & 36 & 74 & 60 & 118 & 54 & 170 & 235 & 137 & 150 \\
\hline $\mathrm{Cu}$ & 100 & 145 & 117 & 126 & 92 & 107 & 117 & 103 & 130 \\
\hline $\mathrm{Zr}$ & 180 & 800 & 690 & 510 & 230 & 76 & 157 & 155 & 203 \\
\hline $\mathrm{Ni}$ & 10 & 23 & 36 & 47 & 16 & 21 & 41 & 34 & 31 \\
\hline Co & 6 & 13 & 16 & 21 & 9 & 23 & 31 & 17 & 24 \\
\hline $\mathrm{Cr}$ & 50 & 45 & 89 & 102 & 33 & 65 & 148 & 183 & 96 \\
\hline $\mathrm{Zn}$ & 131 & 130 & 110 & 135 & 54 & 116 & 142 & 95 & 101 \\
\hline
\end{tabular}

\begin{tabular}{|c|c|c|c|c|c|c|c|c|c|}
\hline & B10 & $\mathrm{C} 1$ & C5 & C6 & C7 & $\mathrm{C} 10$ & C11 & $\bar{X}$ & $\mathrm{C}, \%$ \\
\hline $\mathrm{SiO}_{2}$ & 56.70 & 52.86 & 52.92 & 55.91 & 45.44 & 47.99 & 54.59 & 53.95 & 6.3 \\
\hline $\mathrm{TiO}^{2}$ & 0.98 & 0.72 & 0.85 & 1.02 & 0.30 & 0.60 & 0.50 & 0.99 & 56.6 \\
\hline $\mathrm{Al}_{2} \mathrm{O}_{3}$ & 17.95 & 16.77 & 16.99 & 18.99 & 20.89 & 16.25 & 16.91 & 17.99 & 9.0 \\
\hline $\mathrm{Fe}_{2} \mathrm{O}_{3}$ & 2.54 & 0.67 & 1.92 & 1.04 & 3.39 & 1.09 & 2.78 & 1.55 & 106.8 \\
\hline $\mathrm{FeO}$ & 5.42 & 11.15 & 9.35 & 7.09 & 9.38 & 11.18 & 6.96 & 8.96 & 20.3 \\
\hline $\mathrm{MnO}$ & 0.056 & 0.134 & 0.147 & 0.066 & 0.194 & 0.177 & 0.118 & 0.12 & 33.2 \\
\hline $\mathrm{MgO}$ & 2.22 & 4.40 & 4.32 & 3.54 & 5.20 & 8.64 & 3.79 & 3.95 & 41.2 \\
\hline $\mathrm{CaO}$ & 2.72 & 7.24 & 7.28 & 4.24 & 9.58 & 8.39 & 7.02 & 6.68 & 29.8 \\
\hline $\mathrm{Na}_{2} \mathrm{O}$ & 3.57 & 3.02 & 3.53 & 3.33 & 3.72 & 3.29 & 2.55 & 3.14 & 23.5 \\
\hline $\mathrm{K}_{2} \mathrm{O}$ & 4.15 & 0.84 & 1.02 & 2.54 & 1.11 & 0.86 & 1.38 & 2.09 . & 5.1 \\
\hline $\mathrm{H}_{2} \mathrm{O}^{+}$ & 2.63 & 0.94 & 0.08 & 0.51 & 0.48 & 0.00 & 1.92 & 0.51 & 151.6 \\
\hline Total & 98.94 & 98.74 & 98.41 & 98.28 & 99.68 & 98.47 & 98.52 & & \\
\hline Total Fe* & 8.56 & 13.05 & 12.30 & 8.91 & 13.80 & 13.50 & 10.51 & 11.52 & 14.8 \\
\hline \multicolumn{10}{|c|}{ Trace elements (ppm) } \\
\hline V & 95 & 155 & 180 & 142 & 190 & 210 & 153 & 135 & 43.0 \\
\hline $\mathrm{Cu}$ & 147 & 125 & 117 & 100 & 72 & 113 & 73 & 111 & 19.4 \\
\hline $\mathrm{Zr}$ & 71 & 97 & 102 & 90 & 125 & 70 & 110 & 229 & 99.8 \\
\hline $\mathrm{Ni}$ & 20 & 30 & 18 & 20 & 28 & 16 & 18 & 25.6 & 39.8 \\
\hline Co & 16 & 20 & 21 & 16 & 19 & 20 & 17 & 18.1 & 32.5 \\
\hline $\mathrm{Cr}$ & 40 & 113 & 68 & 62 & 100 & 91 & 83 & 85.5 & 46.6 \\
\hline $\mathrm{Zn}$ & 77 & 106 & 125 & 98 & 92 & 119 & 84 & 107 & 22.1 \\
\hline
\end{tabular}

${ }^{*}$ Calculated as $\mathrm{Fe}_{2} \mathrm{O}_{3}$ 
Table IV - Chemical composition of residual soils

\begin{tabular}{|c|c|c|c|c|c|c|c|c|c|c|}
\hline & A5 & A9 & A10 & A11 & A6 & A7 & B4 & B6 & B7 & B8 \\
\hline $\mathrm{SiO}_{2}$ & 41.51 & 43.12 & 44.24 & 36.93 & 31.94 & 30.56 & 35.65 & 44.20 & 36.63 & 38.98 \\
\hline $\mathrm{TiO}_{2}$ & 2.73 & 0.98 & 1.04 & 1.08 & 2.86 & 3.42 & 0.71 & 0.26 & 0.69 & 0.93 \\
\hline $\mathrm{Al}_{2} \mathrm{O}_{3}$ & 25.32 & 30.06 & 26.62 & 29.75 & 28.92 & 29.17 & 34.34 & 30.95 & 32.53 & 34.02 \\
\hline $\mathrm{Fe}_{2} \mathrm{O}_{3}$ & 9.14 & 5.59 & 6.88 & 7.56 & 16.73 & 15.17 & 5.45 & 3.71 & 6.33 & 7.00 \\
\hline $\mathrm{FeO}$ ? & 2.55 & 0.66 & 0.61 & 0.55 & 0.79 & 2.08 & 1.50 & 1.26 & 0.20 & 0.19 \\
\hline $\mathrm{MnO}$ & 0.048 & 0.022 & 0.023 & 0.024 & 0.070 & 0.056 & 0.036 & 0.051 & 0.030 & 0.018 \\
\hline $\mathrm{MgO}$ & 1.25 & 0.49 & 1.16 & 0.43 & $\operatorname{tr}$ & tr & 1.09 & 0.70 & 0.23 & 0.23 \\
\hline $\mathrm{CaO}$ & 0.95 & $\operatorname{tr}$ & 0.71 & $\operatorname{tr}$ & $\mathrm{tr}$ & tr & tr & 1.40 & $\operatorname{tr}$ & $\mathrm{tr}$ \\
\hline $\mathrm{Na}_{2} \mathrm{O}$ & 0.69 & 0.54 & 0.40 & 0.20 & $\operatorname{tr}$ & $\operatorname{tr}$ & 0.20 & 1.87 & 0.20 & 0.20 \\
\hline $\mathrm{K}_{2} \mathrm{O}_{+}$ & 2.07 & 3.70 & 4.17 & 2.61 & 0.10 & 0.31 & 0.90 & 1.80 & 0.57 & 0.10 \\
\hline $\mathrm{H}_{2} \mathrm{O}$ & 13.25 & 13.33 & 13.42 & 20.17 & 17.58 & 18.47 & 18.56 & 12.55 & 20.74 & 17.48 \\
\hline Total & 99.54 & 98.49 & 99.27 & 99.30 & 98.99 & 99.24 & 98.44 & 98.75 & 98.15 & 99.15 \\
\hline Total Fe* & 11.97 & 6.32 & 7.56 & 8.17 & 17.61 & 17.48 & 7.11 & 5.11 & 6.55 & 7.21 \\
\hline \multicolumn{11}{|c|}{ Trace elements (ppm) } \\
\hline $\mathrm{V}$ & 145 & 68 & 102 & 75 & 225 & 250 & 91 & 95 & 102 & 96 \\
\hline $\mathrm{Cu}$ & 37 & 16 & 18 & 15 & 15 & 17 & 37 & 24 & 37 & 43 \\
\hline $\mathrm{Zr}$ & 2000 & 620 & 1200 & 690 & 1250 & 2500 & 250 & 94 & 305 & 330 \\
\hline $\mathrm{Ni}$ & 42 & 19 & 31 & 11 & 11 & 19 & 29 & 11 & 18 & 31 \\
\hline $\mathrm{Co}$ & 22 & 9 & 9 & 4 & 5 & 13 & 9 & 7 & 5 & 8 \\
\hline $\mathrm{Cr}$ & 130 & 64 & 220 & 79 & 197 & 140 & 96 & 85 & 110 & nd \\
\hline $\mathrm{Zn}$ & nd & 138 & 175 & 108 & nd & 188 & 131 & 123 & nd & nd \\
\hline
\end{tabular}

\begin{tabular}{|c|c|c|c|c|c|c|c|c|c|c|}
\hline & B9 & $\mathrm{C} 2$ & C3 & $\mathrm{C} 4$ & $\mathrm{C} 8$ & $\mathrm{C} 12$ & $\mathrm{C} 13$ & $\mathrm{C} 14$ & $\mathrm{X}$ & $\mathrm{C}, \%$ \\
\hline $\mathrm{SiO}_{2}$ & 44.57 & 26.44 & 43.88 & 39.96 & 40.17 & 36.89 & 27.55 & 36.25 & 37.75 & 15.0 \\
\hline $\mathrm{TiO}_{2}$ & 0.41 & 0.73 & 3.78 & 3.83 & 2.64 & 1.53 & 4.33 & 3.50 & 21.97 & 70.3 \\
\hline $\mathrm{Al}_{2} \mathrm{O}_{3}$ & 28.51 & 36.03 & 22.52 & 24.32 & 30.81 & 30.05 & 26.68 & 31.64 & 29.57 & 12.0 \\
\hline $\mathrm{Fe}_{2} \mathrm{O}_{3}$ & 1.85 & 13.44 & 8.35 & 15.30 & 10.22 & 17.00 & 25.83 & 13.55 & 10.50 & 56.9 \\
\hline $\mathrm{FeO}$ & 1.24 & 0.23 & 2.07 & 1.76 & 0.46 & 0.18 & 0.00 & 0.00 & 0.91 & 87.9 \\
\hline $\mathrm{MnO}$ & 0.026 & 0.065 & 0.100 & 0.087 & 0.070 & 0.024 & 0.11 & 0.095 & 0.05 & 60.0 \\
\hline $\mathrm{MgO}$ & 0.58 & 0.46 & 1.77 & $\operatorname{tr}$ & 0.37 & $\operatorname{tr}$ & $\operatorname{tr}$ & tr & 0.50 & 100.0 \\
\hline $\mathrm{CaO}$ & $\operatorname{tr}$ & $\operatorname{tr}$ & $\operatorname{tr}$ & $\operatorname{tr}$ & $\mathrm{tr}$ & tr & 0.46 & $\mathrm{tr}$ & 0.23 & 170.8 \\
\hline $\mathrm{Na}_{2} \mathrm{O}$ & tr & tr & $\mathrm{tr}$ & $\operatorname{tr}$ & 0.20 & $\operatorname{tr}$ & tr & 0.20 & 0.28 & 157.1 \\
\hline $\mathrm{K}_{2} \mathrm{O}$ & 2.12 & 0.66 & 1.96 & 0.12 & 0.37 & tr & 0.36 & $\operatorname{tr}$ & 1.22 & 106.6 \\
\hline $\mathrm{H}_{2} \mathrm{O}$ & 19.29 & 22.31 & 14.76 & 13.55 & 14.57 & 13.67 & 13.02 & 13.36 & 16.11 & 19.7 \\
\hline Total & 98.60 & 100.36 & 99.19 & 98.93 & 99.88 & 99.34 & 98.24 & 98.59 & & \\
\hline Total Fe* & 3.23 & 13.70 & 10.64 & 17.25 & 10.73 & 17.20 & 25.83 & 13.55 & 11.51 & 50.7 \\
\hline \multicolumn{11}{|c|}{ Trace elements (ppm) } \\
\hline V & 57 & 240 & 120 & 206 & 200 & 233 & 175 & 197 & 149 & 44.9 \\
\hline $\mathrm{Cu}$ & 25 & 47 & 50 & 21 & 84 & 56 & 70 & 41 & 36.3 & 54.7 \\
\hline $\mathrm{Zr}$ & 460 & 125 & 2000 & 3000 & 202 & 360 & 2500 & 940 & 1046 & 90.5 \\
\hline $\mathrm{Ni}$ & 18 & 35 & 36 & 15 & 333 & 10 & 14 & 18 & 22.3 & 45.9 \\
\hline Co & 13 & 18 & 22 & 9 & 14 & 5 & 2 & 11 & 10.3 & 56.7 \\
\hline $\mathrm{Cr}$ & 60 & 236 & 75 & 181 & 73 & nd & 620 & 138 & 156 & 86.8 \\
\hline $\mathrm{Zn}$ & 133 & nd & 281 & 147 & nd & nd & nd & 169 & 157 & 32.4 \\
\hline
\end{tabular}

*Calculated as $\mathrm{Fe}_{2} \mathrm{O}_{3}$ 
Data of Tables III, IV and V show that an extensive removal of soluble components as alkalies and alkaline earths has occurred during weathering. Magnesium, calcium and sodium were depleted up to $90 \%$ by weight; loss of potassium was more limited $(50-70 \%)$. Considering the absolute averages, the strong increase of alumina, ferric iron and water in soil is accompanied by an obvious concentration of some elements, like $\mathrm{Ti}, \mathrm{Zr}, \mathrm{V}, \mathrm{Cr}$, usually characterizing sesquoxide weathering products (see for example Short, 1961; Melfi and Levi, 1968; Sinclair, 1967; Oertel and Giles, 1967). Generally, there is no progressive gain or loss of elements from the base of the profile to the top as would be expected during continual weathering. Particularly local concentration of ferric or aluminium oxides which may be due to the original composition of the rock and/or to peculiar physico-chemical conditions of local weathering have produced fluctuations independently from its location in the profile. The presence of microenvironmental conditions responsible for the formation of various types of soil may be shown by considering the behaviour of titania. In profiles $A$ and $B$ titania exhibits definite mobility relative to alumina (Table V) while the contrary occurs in the profile $C$. Provided titanium forms $\mathrm{Ti}(\mathrm{OH})_{4}$ when it is released from magnetite, biotite and pyroxene of the parent granulites, and considering that Kovalenko and Nestorovich (1952) report this compound as soluble at $\mathrm{pH}$ below 5 while alumina is precipitated at value above 4 (profiles $\mathrm{A}$ and $\mathrm{B}$ have $\mathrm{pH}$ between 4 and 5), local movement of titanium relative to alumina is possible.

Tabre V - Weathering balance of the main elements within the various profiles

\begin{tabular}{|c|c|c|c|c|c|c|c|c|c|}
\hline & \multicolumn{3}{|c|}{ Profile A } & \multicolumn{3}{|c|}{ Profile B } & \multicolumn{3}{|c|}{ Profile C } \\
\hline & $\begin{array}{l}\text { Fresh } \\
\text { granulite }\end{array}$ & $\begin{array}{l}\text { Residual } \\
\text { soil }\end{array}$ & $\begin{array}{l}\text { Gains } \\
\text { and } \\
\text { losses, \% }\end{array}$ & $\begin{array}{l}\text { Fresh } \\
\text { granulite }\end{array}$ & $\begin{array}{l}\text { Residual } \\
\text { soil }\end{array}$ & $\begin{array}{l}\text { Gains } \\
\text { and } \\
\text { losses, \% } \%\end{array}$ & $\begin{array}{l}\text { Fresh } \\
\text { granulite }\end{array}$ & $\begin{array}{l}\text { Residual } \\
\text { soil }\end{array}$ & $\begin{array}{l}\text { Gains } \\
\text { and } \\
\text { losses, \% }\end{array}$ \\
\hline $\mathrm{SiO}_{2}$ & 56.13 & 38.05 & -62 & 54.25 & 40.00 & -60 & 51.61 & 35.88 & -57 \\
\hline $\mathrm{TiO}_{2}^{2}$ & 1.56 & 2.02 & -27 & 0.81 & 0.60 & -60 & 0.66 & 2.90 & +173 \\
\hline $\mathrm{Al}_{2} \mathrm{O}_{3}$ & 15.94 & 28.31 & - & 17.10 & 31.87 & - & 17.97 & 28.87 & - \\
\hline $\mathrm{Fe}_{2} \mathrm{O}_{3}$ & 0.76 & 10.18 & +651 & 2.10 & 4.87 & +24 & 1.82 & 14.81 & +400 \\
\hline $\mathrm{FeO}$ & 9.66 & 1.21 & -93 & 7.99 & 0.87 & -94 & 9.19 & 0.67 & -95 \\
\hline $\mathrm{MnO}$ & 0.09 & 0.04 & -78 & 0.13 & 0.03 & -85 & 0.14 & 0.06 & -71 \\
\hline $\mathrm{MgO}$ & 2.66 & 0.57 & -88 & 4.01 & 0.57 & -92 & 4.98 & 0.40 & -95 \\
\hline $\mathrm{CaO}$ & 5.38 & 0.31 & -97 & 7.24 & 0.32 & -98 & 7.29 & 0.10 & -99 \\
\hline $\mathrm{Na}_{2} \mathrm{O}$ & 3.40 & 0.32 & -94 & 2.77 & 0.50 & -90 & 3.24 & 0.09 & -98 \\
\hline $\mathrm{K}_{2} \mathrm{O}$ & 3.24 & 2.16 & -63 & 1.90 & 1.10 & -69 & 1.29 & 0.51 & -75 \\
\hline $\mathrm{H}_{2} \mathrm{O}^{+}$ & 0.23 & 16.04 & +3865 & 0.62 & 17.72 & +1424 & 0.65 & 15.03 & +1335 \\
\hline Total loss & & $44 \%$ & & & $47 \%$ & & & $38 \%$ & \\
\hline
\end{tabular}

Variations in geochemical trends induced by weathering As was seen by the $C$ per cent data reported in Tables III and IV, weathering produced an increased dispersion of almost all the elements (water and ferric iron behave of course contrarily even though can vary much more in granulites in consequence of local metamorphic conditions of $\mathrm{O}_{2}$ and $\mathrm{H}_{2} \mathrm{O}$ pressure). This implies that weathering must influence relationships between elements, which geochemical trends were influenced or established should be investigate. On the basis of the average content in rocks and soils, the geochemical balance for the 
various elements can be schematized as follow:

in weathering material $\left\{\begin{array}{l}\mathrm{Zr}, \mathrm{Ti} \text { (strong), } \mathrm{Cr}, \mathrm{Zr}, \mathrm{V} \text { (medium or low) enrichment; } \\ \mathrm{Cu} \text { (strong), Mn, Co (medium or low) loss. }\end{array}\right.$

Let us test both in fresh rocks and in soils the relationships between some ferromagnesian elements (chromium, zinc, vanadium and manganese) and iron (Fig. 3). These elements are commonly associated with iron in magmatic rocks (Raber et al., 1963; Gruza, 1965) as well as in granulitic rocks (Sighinolfi, 1970 and 1971).

To test correlation grade between elements correlation coefficient $r$ for some pairs of elements in fresh rocks and residual soil was calculated; the results are reported on the figures. As can be seen on Fig. 3, a general correlation ferromagnesian-iron in fresh rocks may be considered to exist. In soil, chromium, vanadium and zinc mantain or establish closer relationships with iron (limitation of these assertions for zinc are due to scarce number of $\mathrm{Zn}$ data in soil) whereas manganese seems vary independently from iron. In addition, as can be seen on Fig. 3 and as indicated by average contents, chromium, zinc and vanadium are concentrated and manganese impoverished in soil with respect to iron. The independence of $\mathrm{Mn}$ and $\mathrm{Fe}$ in the soil can be easily explained by considering that manganese requires higher oxidation condition and higher $\mathrm{pH}$ to precipitate than iron or if both elements form colloidal oxides during the first stage of weathering (in this case unlikely) they must be stable under different conditions (Krauskopf, 1957 and 1967, p. 268; Hem, $1960 a$ and $1960 b$ ).

Particular oxidation conditions would also explain the concentration of vanadium and chromium in soil: contrary to $\mathrm{Mn}$, the oxidized form, for example $\left(\mathrm{VO}_{3}\right)^{2-}$ and $\left(\mathrm{CrO}_{4}\right)^{2-}$, of these two elements are more soluble. Therefore limited oxidation conditions during the first stage of weathering can account for the results obtained for $\mathrm{Mn}, \mathrm{V}$ and $\mathrm{Cr}$ in soil.

Fig. 4 shows relationships between $\mathrm{Ni}$, $\mathrm{Co}$ and $\mathrm{Cr}$, elements which normally show good correlations in any $\mathrm{ty}_{3} \mathrm{e}$ of crystalline rock. The correlation $\mathrm{Ni}-\mathrm{Cr}$, fairly closed in granulites, disappears completely in soil, whereas $\mathrm{Ni}$ and $\mathrm{Co}$ increase their correlation in soil, although Co is clearly removed relative to $\mathrm{Ni}$ during alteration. $\mathrm{Ni}^{2+}$ and $\mathrm{Co}^{2+}$ are oxidized only under high Eh conditions so that they remain in solution. But there is a tendency for $\mathrm{Ni}$ to be retained in some silicate (see the behaviour of $\mathrm{Ni}$ in alteration of ultrabasic rocks) and this explains the partial removal of Co relative to $\mathrm{Ni}$ in soil.

Relationships between three typical hydrolized elements, $\mathrm{Zr}, \mathrm{Cr}$ and $\mathrm{Ti}$, are shown on Fig. 5; their mutual correlation increases markedly in altered materials, underlining the influence of some physico-chemical factor, such as ionic potential and possibly adsorption phenomena in establishing definite geochemical trands. Zirconium shows the strongest absolute rate of increase in concentration in soils: here its average content is more than four times that in granulites. This does not agree with the results of the isoalumina calculations, from which it would seem that loss of material during weathering should not exceed 50 per cent. Two explanations can be proposed:

a) Because the residual soil is produced by "mature" weatherıng (Haantjens and Bleeker, 1970) and under strong drainage conditions, a partial loss of alumina could be considered (Delvigne, 1965; Lelong, 1967; Hendricks and Whittig, 1968). This of course would cause an indirect enrichment of some less mobile elements such as $\mathrm{Zr}$. At this point it must be remembered that geochemistry of zirconium in exogenic cycle is not well known. 


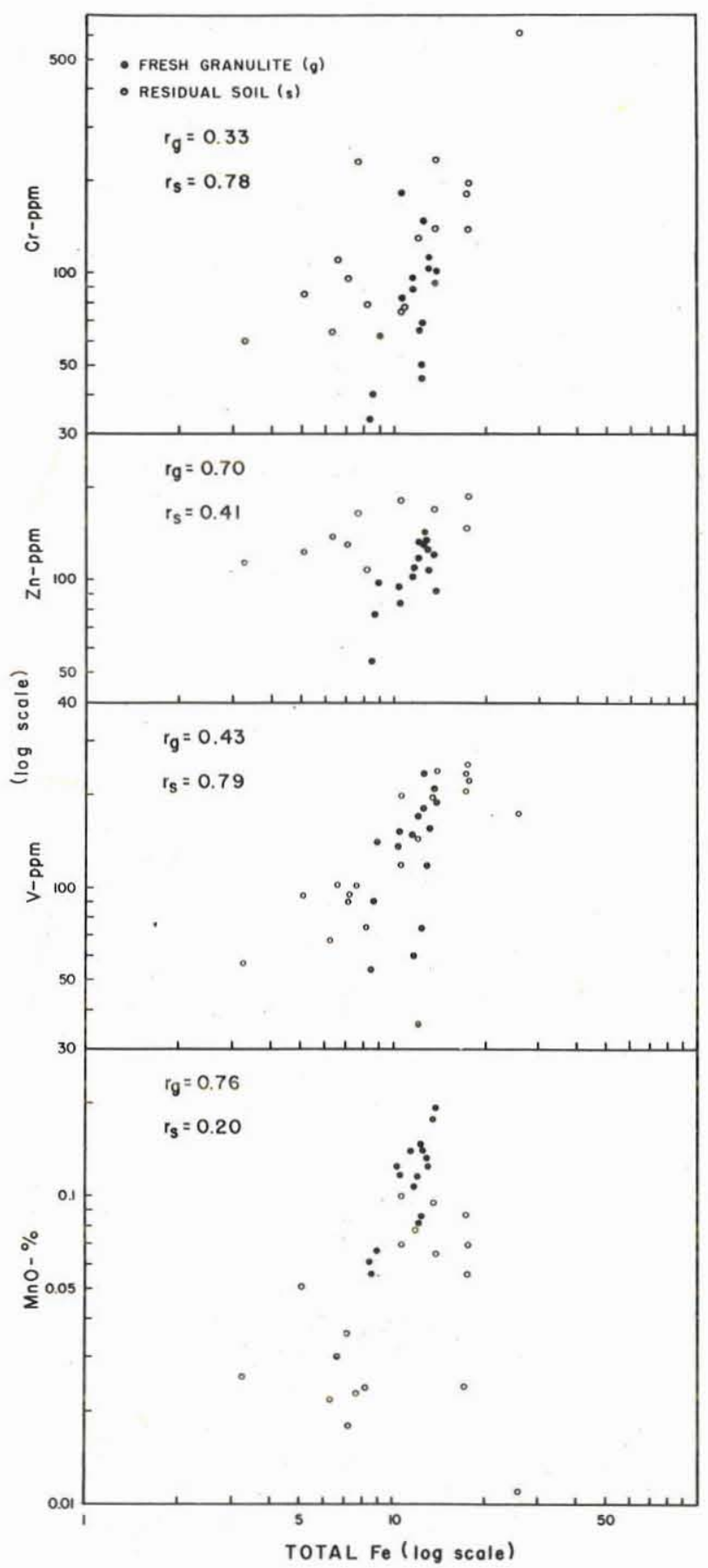

Figure 3 - Relationships between $\mathrm{Cr}, \mathrm{Zn}, \mathrm{V}$ and $\mathrm{MnO}$ contents with the total $\mathrm{Fe}$ content, calculated as $\mathrm{Fe}_{2} \mathrm{O}_{3}$, of both fresh granulite and residual soil derived from it 


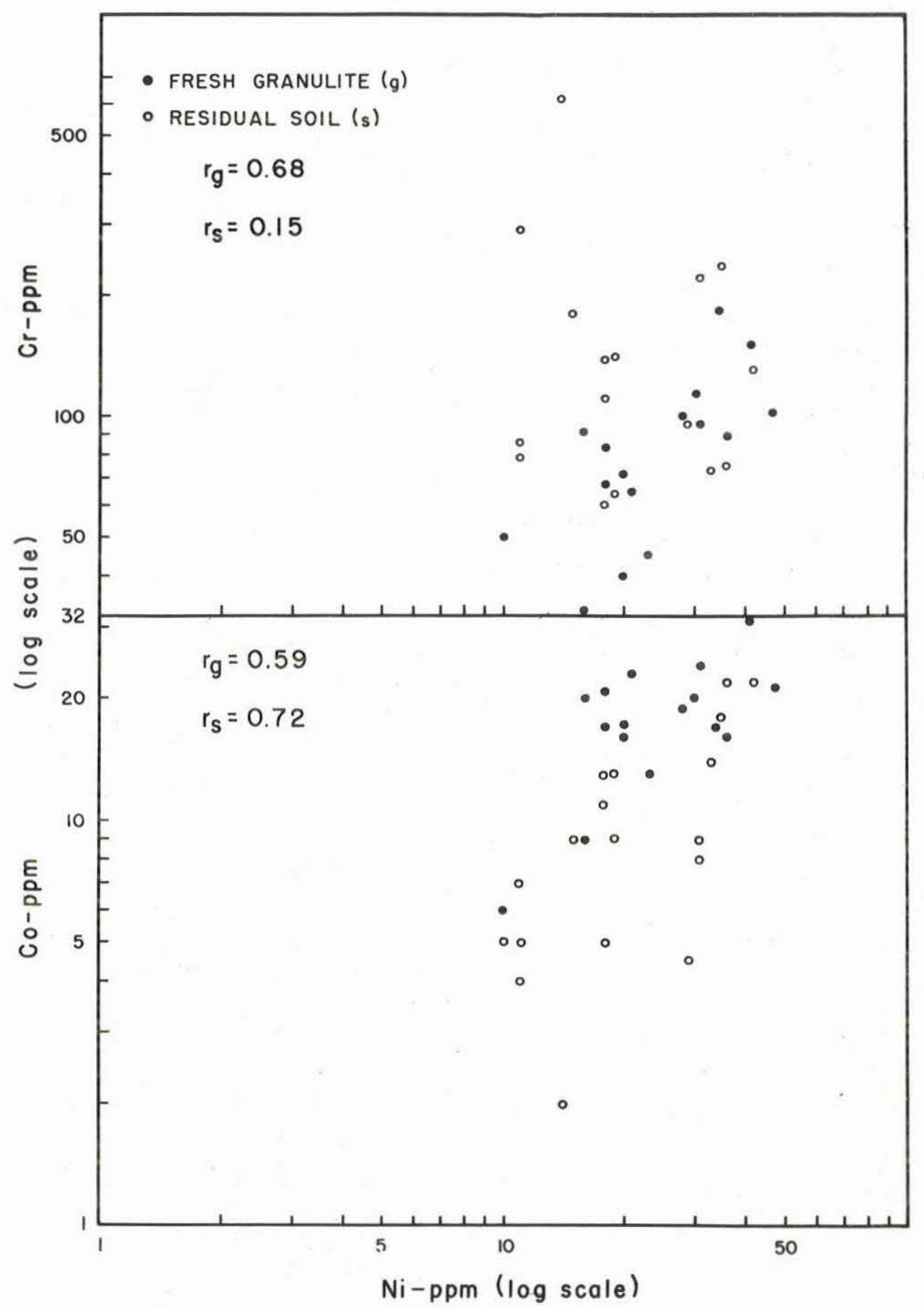

Figure 4 - Relationships between $\mathrm{Cr}$ and Co contents with the Ni content of both fresh granulite and residual soil derived from it 


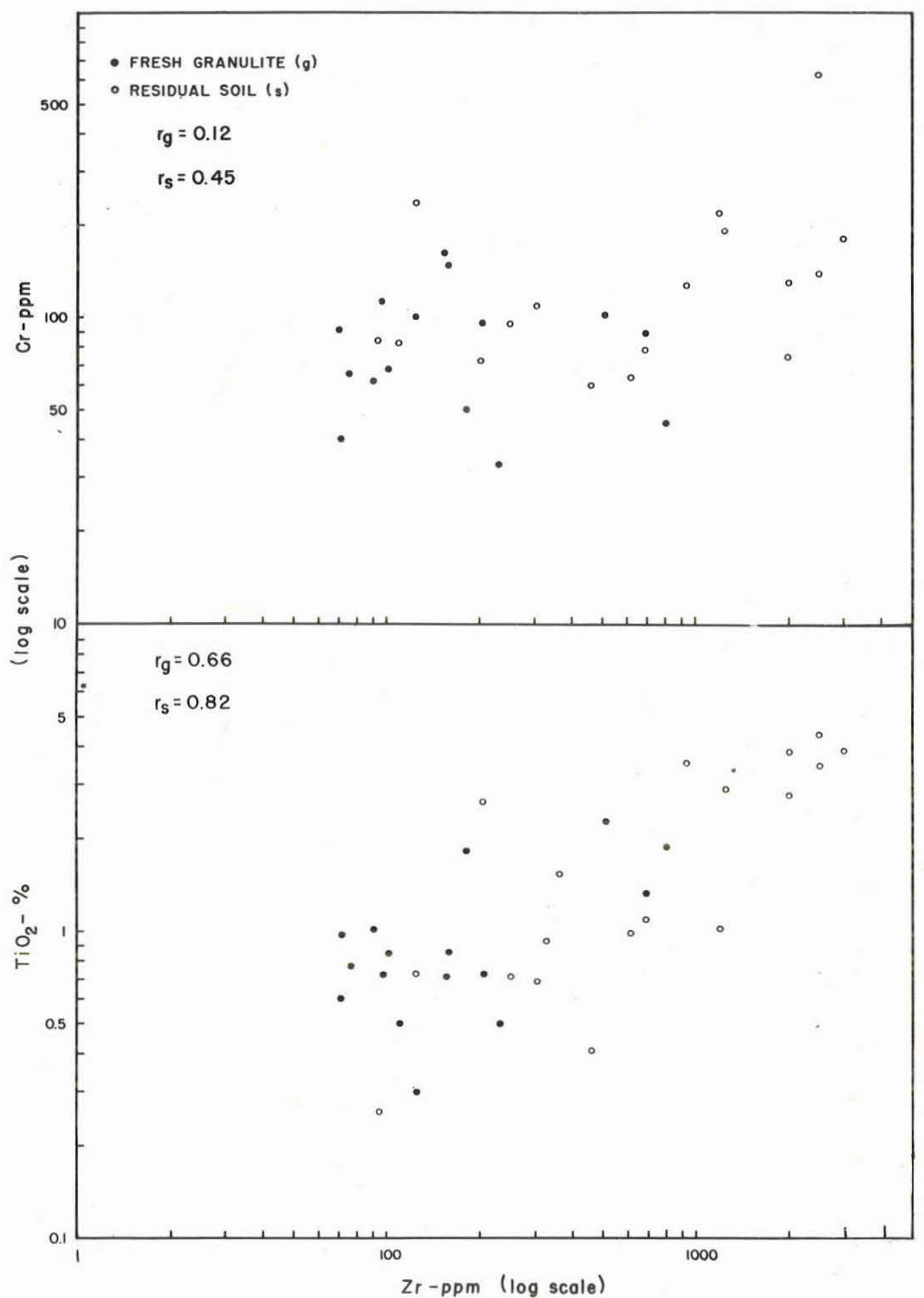

Figure 5 - Relationships between $\mathrm{Cr}$ and $\mathrm{TiO}_{2}$ contents with the $\mathrm{Zr}$ content of both fresh granulite and residual soil derived from it 
b) Owing to the great dispersion shown by $\mathrm{Zr}$ both in rocks and in soil, it may be possible that a bias was introduced during sample collection which influenced the average contents. It seems more plausible that the two factors acted together.

CONCLUSIONS 1) Tropical weathering of granulitic rocks under conditions of very strong drainage produced either gibbsitic or kaolinitic soil, as well as kaolinitic-gibbsitic soil. The transition from one soil type to another is abrupt and occurs in very limited areas. The variation in the chemical composition of horst-rocks and/or in the drainage conditions seems to account for the soil type variation.

2) Almost total disappearance of alkali and alkaline earths (up to $90 \%$ ) and enrichment of hydrolisate elements characterize the residual soils formed. The abnormal enrichment of some elements, like $\mathrm{Zr}$, suggests that alteration may have progressed not under isoalumina conditions but partial removal of Al may have occurred.

3) Weathering has influenced geochemical trends in soils, in particular the relationships between the ferromagnesians $\mathrm{Cr}, \mathrm{Zn}, \mathrm{V}, \mathrm{Mn}$ and $\mathrm{Fe}$. In soil, $\mathrm{Mn}$ is partially depleted and losses its correlation with $\mathrm{Fe}$, whereas $\mathrm{Cr}, \mathrm{Zn}$ and $\mathrm{V}$ maintain or increase the correlation with $\mathrm{Fe}$.

Acknowledgments Financial support for this research was provided by CNPq and BNDE and by Italian GNR. The authors wish to express their gratitude to Prof. M. Formoso and J. Galbraith for suggestions and critical review of the manuscript.

\section{REFERENCES}

BELT, C. B. Jr. - 1964 - Atomic absorption spectrophotometry and the analysis of silicate rocks for copper and zinc. Econ. Geol., 59: 240-258

BERNAS, B. - 1968 - A new method for decomposition and comprehensive analysis of silicates by atomic absorption spectrometry. Anal. Chem, 40:1682-1686

BONIFAS, M. - 1959 - Contribuition a l'étude géochimique de l'altération latéritique. Mémoires du Service de la Carte Géologique d'Alsace et de Lorraine, 17. 159 pp.

CRAIG, D. G. and LOUGHNAN, F. C. - 1964 - Chemical and mineralogical transformation ascompanying the weathering of basic colcanic rocks from Now South Wales. Austr. J. Soil Res., 2(2): $218-234$

DELVIGNE, J. - 1965 - Pédogenèse en zone tropicale. Mem. O.R.S.T.O.M., 13. 177 pp

DELVIGNE, J. - 1967 - Bilans géochimiques de l'altération des roches basiques en Côte-d'Ivoire ferralitique. Rev. Géogr. Phys. et Geol. Dyn., 9(4): $311-320$

FAIRBAIRN, P. E. and ROBERTSON, R. H. - 1966 - Stages in the tropical weathering of Kimberlite. Glay Min., 6(4): 351-370

FUJIMORI, S. - 1968 - Granulitos e charnockitos de Salvador, Bahia. An. Acad. Brasil. Cienc., 40: $181-202$

GRANT, W. H. - 1964 - Chemical weathering of biotite-plagioclase gneiss. Clay and clay Min., (12th Nat. Conf., 1963): 455-463

GRUZA, V. V. - 1965 - An investigation of petrochemical characteristics of rocks of similar composition by the methods of mathematical statistics. Geochemistry (USSR) (English Transl.), 2: 88-91

HAANTJENS, H. A. and BLEEKER, P. - 1970 - Tropical weathering in the territory of Papua and New Guinea. Aust. J. Soil Res., 8: 157-1.77

HEM, J. D. - 1960a - Restraints on dissolved ferrous iron imposed by bicarbonate redox potencial and pH. U.S. Geol. Surv. Water-Supp. Pap., 1459-B: 33-55

HEM, J. D. - 1960b - Some chemical relationships among sulfur species and dissolved ferrous iron. U.S. Geol, Surv. Water-Supp. Pap., 1459-G: 57-73

HENDRICKS, D. M. and WHITTIG, L. D. - 1968a - Andesite weathering. I. Mineralogical transformations from andesite to saprolite. J. Soil Sci., 19: 135-146 
HENDRICKS, D. M. and WHITTIG, L. D. - 1968b - Andesite weathering II. Geochemical changes from andesite to saprolite. J. Soil Sci., 19: 147-153

KABATA-PENDIAS, A. and RYKA, W. - 1968 - Weathering of biotite gneiss in the paleozoic period. 9th Intern. Congr. Soil Sci., Adelaide, 4: 381-390

KOVALENKO, P. N. and NESTOROVICH, V. N. - 1952 - Polarographic determination of the onset of precipitation of metal hydroxides and solubility products of aluminium and titanium hydroxides. Ukrain. Chem. J., 18: 634-640

KRAUSKOPF, K. B. - 1957 - Separation of manganese from iron in sedimentary processes. Geochim. Cosmochim. Acta. 12: 61-84

KRAUSKOPF, K. B - 1967 - Introduction to geochemistry. McGraw-Hill Ed., Inc. 721 pp.

LELONG, F. - 1967 - Nature et genese des produits d'altération de roches cristallines sous climat tropical humide (Guyane française). These Fac. Sci. Nancy, 182 pp.

LEVI, F. and MELFI, A. J. - 1972 - Geochemical and mineralogical study on the first stages of weathering of basic and related rocks. Part 2 - Geochemical study. Rev. Brasil. de Geocien., 2(1): 1-7

McLAUGHLIN, R. J. W. - 1965 - Geochemical changes due to weathering under varying climatic conditions. Geochim. Cosmochim. Acta. 8: 109-130

MELFI, A. J. and LEVI, F. - 1968 - Geochemical and mineralogical study of the first stages of weathering of basic and related rocks. 23rd Inter. Geol. Congr., Prag, Abstract, 163

MELFI, A. J. and LEVI, F. - 1971 - Geochemical and mineralogical study on the first stages of weathering of basic and related rocks. Part 1 - Mineralogical study. Rev. Brasil. de Geocien., 1(1): 22-28

MONIZ, A. C. and JACKSON, M. L. - 1967 - Quantitative mineralogical analysis of Brazilian soils developed from basic rocks and slate. Wisconsin Soil Science Report 212. 74 pp.

OLIVEIRA, M.A.F.T. - 1970 - Contribuição para o conhecimento petrológico de Salvador, Bahia-Brasil. Garcia de Orta (Lisboa), 18: 229-240

OERTEL, A. C. and GILES, J. B. - 1967 - Development of a red-brown earth profile. Austr. J. Soil Res., 5: 133-147

RADER, L. F., SWADLEY W. C., HUFFMAN, C., Jr. and LIPP H. H. - 1963 - New chemical determination of zinc in basalts, and rocks of similar composition. Geochim. Cosmochim, Acta., 27: 695-714

SHORT, N. M. - 1961 - Geochemical variations in four residual soils. Journ. Geol., 69: 534-571

SIGHINOLFI, G. P. - 1966 - Determinazione di alcuni elementi minori in campioni di rocce standards. Period. Mineral. (Rome), 35: 769-780

SIGHINOLFI, G. P. - 1968 - The zirconium content in some standard rock samples. Atti Soc. Tosc. Sci. Nat., 74: 626-629

SIGHINOLFI, G. P. - 1970 - Investigations into the deep levels of the continental crust: petro$\operatorname{logy}$ and chemistry of the granulite facies terrains of Southern Bahia (Brazil). Atti Soc. Tosc. Sc. Nat. Mem., A77: 327-341

SIGHINOLFI, G. P. - 1971 - Investigations into deep crustal levels: fractionating effects and geochemical trends related to high-grade metamorphism. Geochim. Cosmochim. Acta, 35: 1 005-1 021

SIEFFERMANN, G. - 1969 - Les sols de quelques régions volcaniques du Cameroun. Thèse Fac. Sci. Strasbourg, 290 pp.

SINCLAIR, I. G. L. - 1967 - Bauxite genesis in Jamaica: new evidence from trace elements distribution. Econ. Geol., 62: 482-486

TARDY, Y. - 1969 - Géochimie des alterations. Étude des arènes et des eaux de quelques massifs cristallins d'Europe et d'Afrique. Memoires du Service de la Carte Geologique d'Alsace et de Lorraine, 31: 199 pp. 